\title{
Commemoration as Nation-Building: The Case of Finland, 1916
}

\section{Nely Keinänen}

\section{Q OpenEdition \\ 1 Journals}

\section{Electronic version}

URL: http://journals.openedition.org/shakespeare/3317

DOI: 10.4000/shakespeare.3317

ISSN: 2271-6424

\section{Publisher}

Société Française Shakespeare

\section{Electronic reference}

Nely Keinänen, "Commemoration as Nation-Building: The Case of Finland, 1916 », Actes des congrès de la Société française Shakespeare [Online], 33 | 2015, Online since 10 October 2015, connection on 07 June 2020. URL : http://journals.openedition.org/shakespeare/3317 ; DOI : https://doi.org/10.4000/ shakespeare.3317

This text was automatically generated on 7 June 2020 .

(c) SFS 


\title{
Commemoration as Nation- Building: The Case of Finland, 1916
}

\author{
Nely Keinänen
}

In their introduction to the Critical Survey volume devoted to "Shakespeare and the Cultures of Commemoration," Ton Hoenselaars and Clara Calvo note that in addition to "enhanc[ing] our appreciation of the function of authorship, the transmission of the text, and dynamics of literary fame" cultures of commemoration "also tend to be complex in social and political terms." ${ }^{1}$ As the wide-ranging volume shows, "we must be prepared to cross regional, national, continental, and linguistic borders, continually reminding ourselves of the very plurality of the cultures we study." Calvo does this admirably in two essays analyzing the 1916 tercentenary. In the first, she contrasts festivities celebrating Cervantes in Spain and Shakespeare in England, finding that "both Shakespeare and Cervantes, and the languages they wrote in, became cultural capital that was symbolically appropriated and molded into icons of patriotic enthusiasm in their respective countries with the help of very similar discourses of nationalism, colonialism, and cultural supremacy." ${ }^{3}$ In a later article, she expands her focus to Germany and France, analyzing the "fights" over Shakespeare, where London and Stratford jostled for the tourist market, England and Germany struggled over ownership of the "Bard", and French appropriations of Henry $V$ affirmed Anglo-French bonds. ${ }^{4}$ Habicht discusses contrasts between German and English commemorations in 1864 and 1916, while Foulkes focuses on events in England during the First World War, with reference also to America and Ireland. ${ }^{5}$ In terms of the 1916 tercentenary, one of the most important surviving documents is Israel Gollancz's monumental A Book of Homage to Shakespeare, published by Oxford University Press in $1916 .{ }^{6}$

Discussed most thoroughly by Coppélia Kahn, ${ }^{7}$ the Homage is striking both as a testament to the global appeal of Shakespeare (no doubt aided by the tenacity of its editor), but also for its revelation of challenges to the British imperialistic project. Kahn in particular focuses on contributions by Douglas Hyde (Ireland), Solomon Tshekisho Plaatje (South Africa), and Maung Tin (Burma), who "make Shakespeare their own, or make their own Shakespeare, employing him in a rearguard action on 
behalf of their own cultures in contradistinction to the Shakespeare who signifies England, empire, and Anglo-Saxon superiority for the British Academy." ${ }^{8}$ The case of Douglas Hyde is particularly interesting, as Hyde had written his tribute in Gaelic, for which he supplied an English translation. Gollancz found the translation too inflammatory and removed or softened the most offensive passages. ${ }^{9}$

In this essay, I will show that the tribute offered by the Finnish poet Eino Leino works in a similar fashion, and suffered a similar fate though not at the hands of Gollancz. Like Hyde, Leino uses the occasion of the tercentenary to comment on local political issues, as the poem ends with a call for Finland to be released from bondage to Russia. Just as the translation of Hyde's Gaelic poem was softened, the English translation of the Leino's poem seems to downplay its political content, though I cannot say whether this was intentional. I will first analyze the poem in the context of Gollancz's Homage, but will then deepen the story by relating the poem's reception in pre-independence Finland, where it was initially censored. By studying the domestic after-life of a poem initially composed for the global homage, we can better understand some of the ways that Shakespeare commemoration was harnessed for local political gain in Finland.

\section{Leino's Brief}

Let me begin with a brief summary of events connected to Gollancz's book. In a letter dated January 14, 1916, Israel Gollancz invited Leino to contribute a poem to the homage to Shakespeare (Figure 1). The poem should be received by March 20. Presumably the same form letter was sent to everyone, but Gollancz had personalized the letter to Leino with the following words: "I much desire to include in the Book some lines in Finnish verse, and should be most grateful to you-Yours very faithfully, I. Gollancz." I do not know how long it would have taken for a letter to travel from London to Helsinki in wartime Europe, but presumably this would not have left much time for composing the poem.

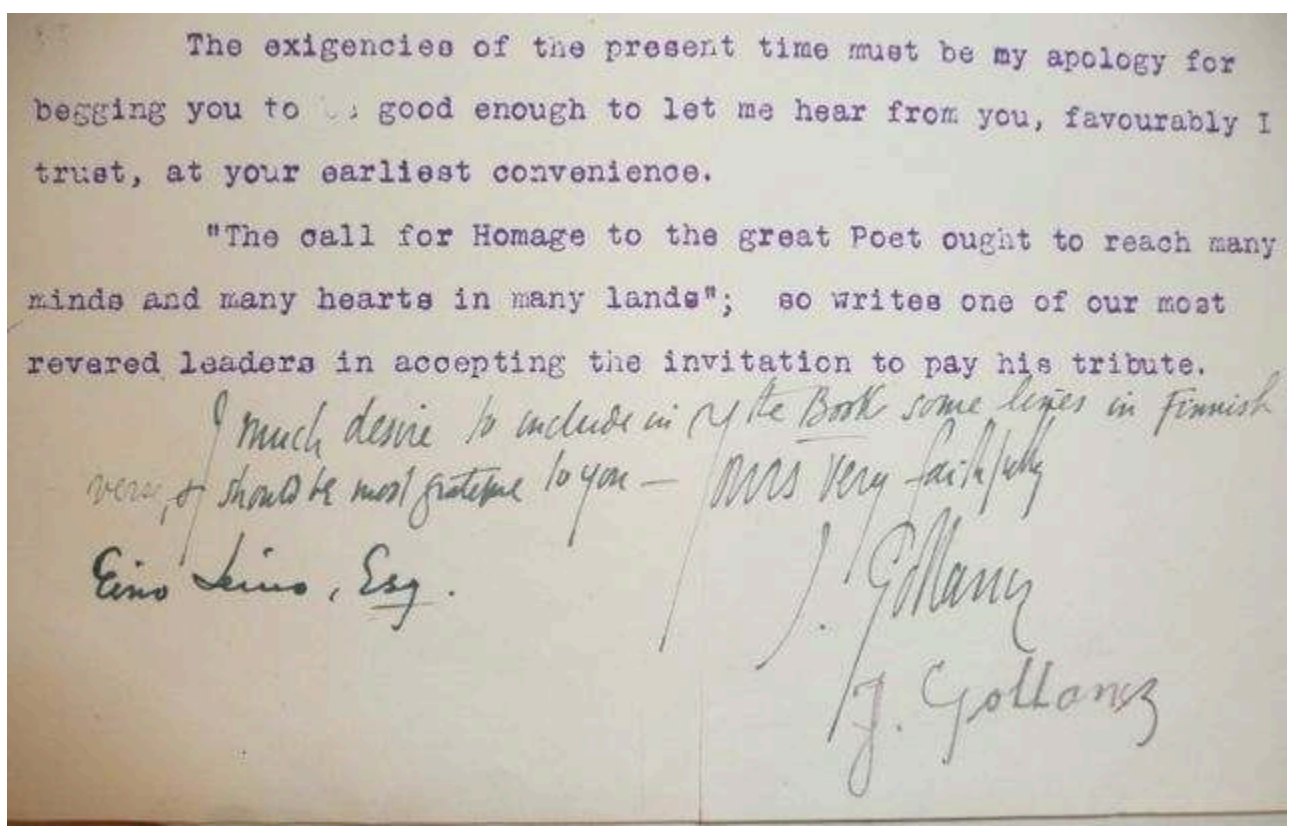


Figure 1: Israel Gollancz's letter to Eino Leino

THE LITERARY ARCHIVES OF THE FINNISH LITERATURE SOCIETY. THE ARCHIVES OF EINO LEINO. LETTER COLLECTION 178.

PHOTO BY N. KEINÄNEN, REPRODUCED WITH KIND PERMISSION OF THE ARCHIVE.

5 I have been unable to find out who might have translated the poem. In his form letter to contributors, Gollancz promises that contributions will be translated, but he makes no specific reference to a translator for this Finnish contribution. There is strong evidence that the poem was translated in Finland: a typed copy of the English translation, "signed by the poet" is included in the Gollancz archive at the Folger Shakespeare Library..$^{10}$ In early 1916 Leino was in Helsinki working on his new literary journal, which will figure later in this story, so it seems likely he signed it there. The Folger archive contains no information on whether the translation was done by Leino himself, or by somebody else. Leino was himself an accomplished translator into Finnish, but it seems unlikely that he would have translated the poem himself into English. ${ }^{11}$ of the other foreign works in the Homage, some have named translators, while others do not.

6 The organization of Homage provides a lesson in the political geography of 1916, with Finland far in the periphery. The book begins with tributes from prominent English writers and scholars, moving on to representatives from the rest of the British Isles, including Ireland, then other countries or territories in the British Empire. The United States comes next, followed by tributes from Western Europe, with countries more or less grouped by region. The Nordic countries come after Holland, and then there's a jump to Russia and other eastern European countries. The entries from Finland are the last ones from Europe, Eino Leino's poem following a tribute from a Polish novelist. After the Finns, there are only a few more entries, from Japan, China, Persia and Armenia.

7 Despite its being on the very periphery of Europe, Finland is represented in Homage by three authors. In addition to Leino, there is a short tribute from the academic Yrjö Hirn, and a long and unfortunately mainly untranslated piece by the novelist Juhani Aho, who writes movingly about the first full-length Finnish-language performance of a Shakespeare play in Finland, a production of Romeo and Juliet in 1881 starring the actress Ida Aalberg. ${ }^{12}$ Aho perceptively raises an important point about these foreign Shakespeares, that while the "mother country" is largely unaware of the fact of translation and performance in these "cultural colonies," their impact can nevertheless be great:

This little reminiscence about the [first Romeo and Juliet] shall serve as the wreath I lay at the feet of the greatest genius of a great nation, a wreath coming from a distant cultural colony of the English culture, the conquest of whom the mother country herself can hardly be aware, but whose possession from that day onwards has been so permanent that our national Finnish stage has thenceforth performed Shakespeare every year. Shakespeare more than any other author. ${ }^{13}$

The presence of as many as three tributes from Finland, which then had a population of around three million, might seem surprising, but since before the turn of the century Finns had actively sought British sympathy in their struggles against Russian repression. In the years leading up to WWI, Finns such as Leo Mechelin and especially Aino Malmberg toured the British Isles trying to drum up support. There was a large pro-Finlandia rally in Trafalgar Square on May 29, 1910, and an Anglo-Finnish society 
was formed in 1911, operating until the start of the war. Through the early part of the war, the official line of the British government was that it had no treaty obligations with Finland. Finland was part of an important supply route from England through Norway and Finland to Russia, whose war efforts on the eastern front became increasingly important as the war dragged on. Parts of the British media, however, were far more supportive of the Finns' claims for autonomy, and there were editorials especially in the Labour and Liberal press on behalf of the Finns. ${ }^{14}$ The future Shakespeare scholar John Dover Wilson, while on the whole sympathetic to Russia, nevertheless wrote in 1914 that "I have lived three years in Finland [1906-1609], and know the weariness of spirit and aching bitterness of heart that comes to a fine and cultured race in its perpetual struggle for liberty against an alien government to whom the word liberty means nothing but rebellion." ${ }^{15}$ Both conservatives and radicals in the UK pointed to the links between the Finnish and the Irish situation. ${ }^{16}$ After the war started, Finland was essentially in a state of martial law, with the last vestiges of autonomy stripped away. ${ }^{17}$ Given this political climate, it is quite likely that Finnish intellectuals and artists would have seized the chance to contribute to a book which had the potential to publicize the Finnish cause in Britain, and clearly had the contacts to do so.

\section{The Poem and its English Translation}

9 As we saw above, Juhani Aho, like many others in the Homage, comments in his tribute on Shakespeare's unique genius. Leino, by contrast, perhaps because of his political agenda of elevating the Finns, views Shakespeare as one of a line of great writers, starting with the Greeks. ${ }^{18}$ Leino's poem begins with a two-part literary history: first the Greeks, and then Shakespeare, created unforgettable characters: ${ }^{19}$

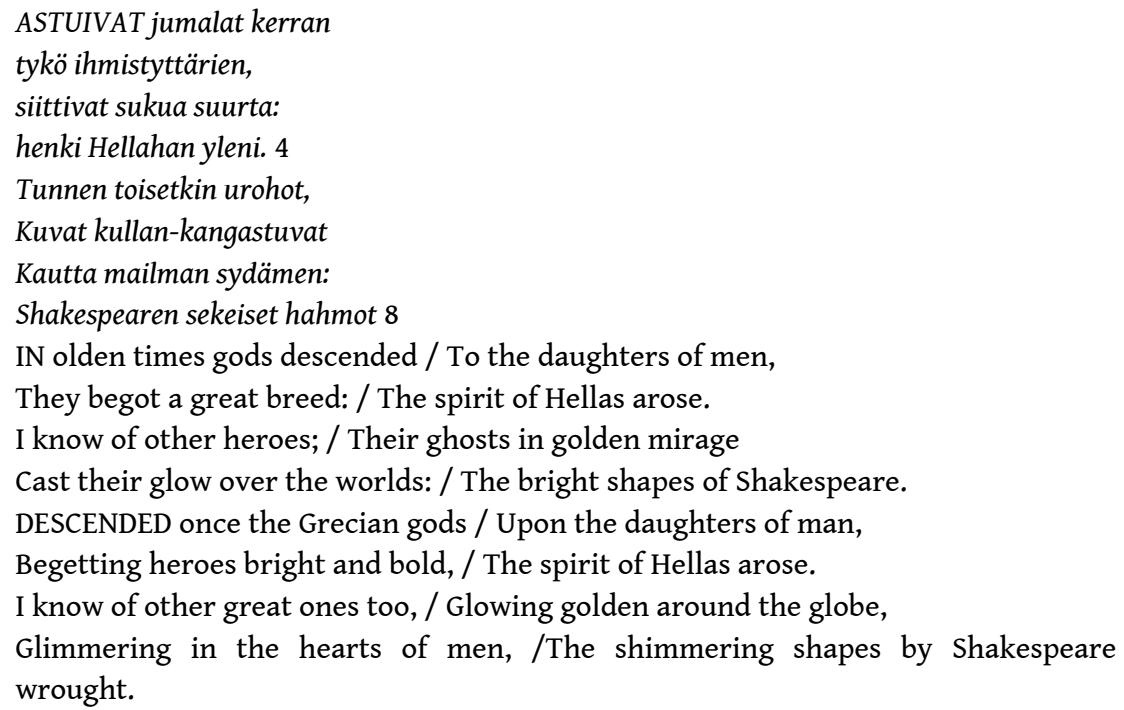
Interestingly, at the beginning of the poem, the speaker focuses on the Greeks as the creators of legends, but in the second stanza there is a clear focus on Shakespeare's characters, rather than Shakespeare the writer: the "great ones" (5), paralleling the "heroes" (3) of the first stanza, are revealed in line 8 to be Shakespeare's characters, not Shakespeare himself.

In the third stanza, Leino introduces a third group "rising up" (9) in the bleak forests of Finland, though here the group seems not to be literary creations but producers of 
song. There may be something vaguely threatening about this third group, emphasized by the $/ k /$ alliteration on four words in two lines, as well as by the trochaic beat (9-10). Leino's poem is written in the same verse form as the Kalevala, the Finnish national epic, trochaic tetrameter with heavy use of alliteration but not much end rhyme. These rhythmic and alliterative echoes of the Kalevala are an important part of the poem's political effect, as the very form allows Leino to make references to the Finns without actually naming them (e.g. all the $/ \mathrm{k} /$ alliteration alludes to the word Kalevala and other words associated with the Finnish people and culture which happen to have the same sound). ${ }^{20}$

11 The fourth stanza begins with a repetition of the first word of the poem, more groups are stepping down, again increasing the tension in the poem as more groups rise up to join the Finns from the land of Kalevala. All of these groups are people similarly being oppressed by the Russians, the Lapps in the north, the Estonians (who declared autonomy in 1917, and independence in 1918, only to be re-occupied by the Soviet Union in the 1940s), and the Karelians, a group which was spread across parts of Finland and Russia and was thus separated when Finland declared independence. All of these oppressed peoples thus join Finland in celebrating Shakespeare, the great man from the island country.

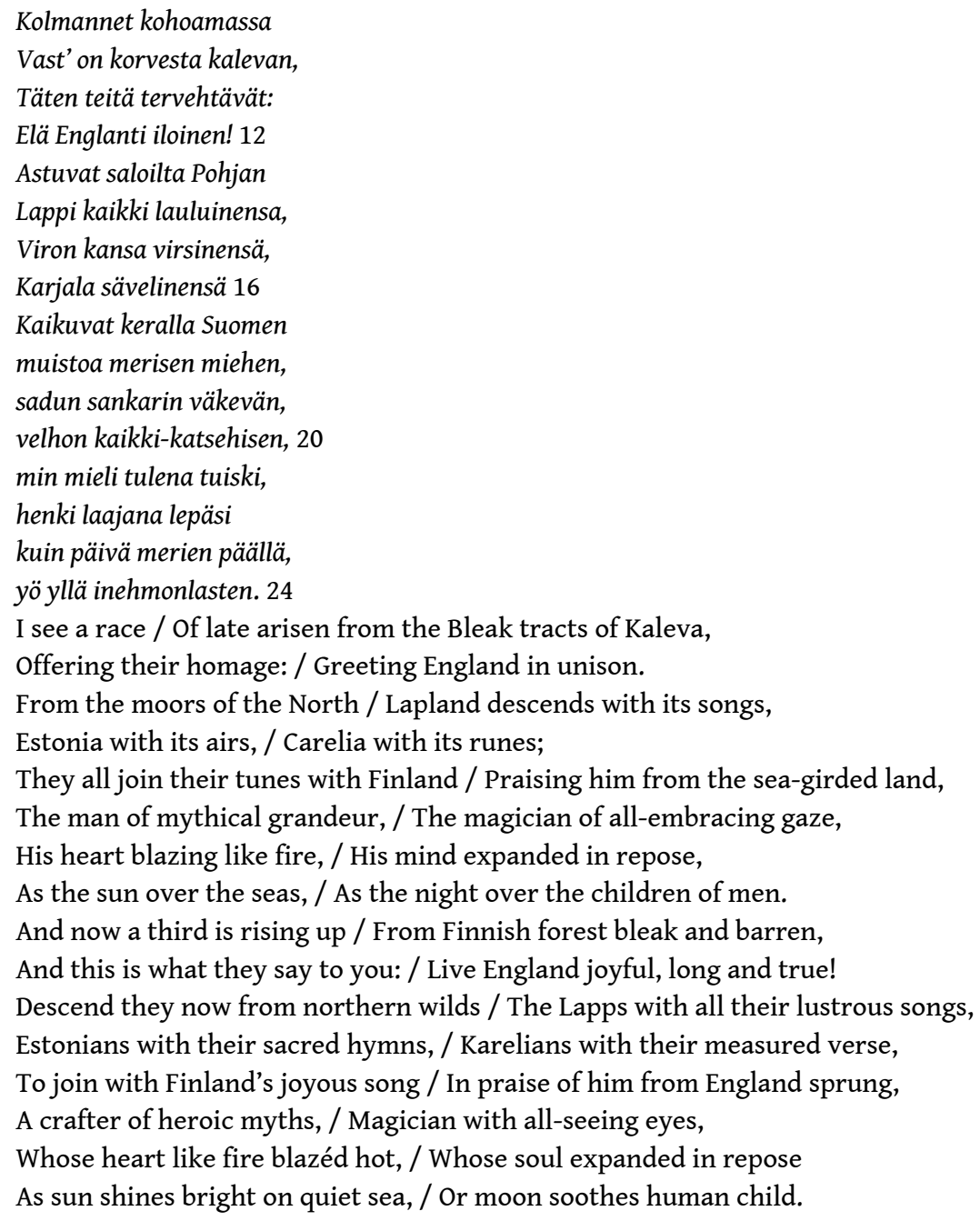

12 It strikes me here that the published English translation lacks the force of the original, mainly due to the lack of a strong rhythm as well as the absence of alliteration. The 
switch in verb forms at the beginning of this section also seems significant - Kolmannet kohoamassa (9) [literally: a third is rising up] is in the progressive verb form, an action taking place right now, though the published translation (center column) has this happening in the past ("I see a race / Of late arisen..."). The published translation also loses the three-part structure of the original: first Greeks, then Shakespeare, and now Finns - a third group is rising up, equal to these predecessors. This rising is further accentuated in the Finnish by the repetition with contrast of the verb which starts the poem: the Greeks astuivat (1), stepped or came down in the past tense, whereas at the beginning of the fourth stanza the verb switches to the present tense, astuvat (13). In the Finnish, the emphasis is on the action, the movement of peoples with their songs, but this is weakened in the published translation, as in the third stanza the agency is shifted from the third group rising to the poet who "sees a race" (9) and in the fourth stanza by the moving of the verb from the first word to the middle of the second line (10).

13 At the end of the poem, the focus returns to Finland, the tribe of the "kannel" or kantele. The kantele is a dulcimer-like folk instrument, with which the bards who originally sung the Kalevala accompanied themselves. ${ }^{21}$ The speaker wishes that their voice, too, will one day ring out along with the voices of the free. Here the alliteration on the $/ \mathrm{k} /$ sound is positively remarkable, repeating three times in the first line (with two further repetitions within the words), and twice in the second and third lines.

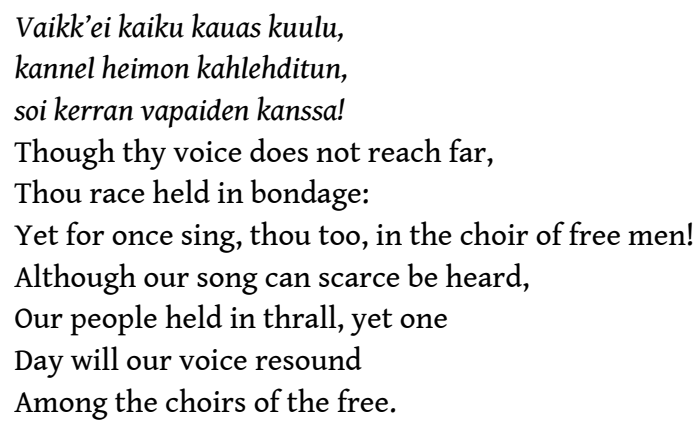

Leino seems to have been fond of $/ k$ / alliteration, and indeed of the words kaiku (echo), kauas (far) and kuulu (be heard), as he uses them in another political poem during the same period. In 1916, one of Leino's books (Elämän Koreus, The Beauty/Brightness of Life) was being confiscated from bookshops..$^{22}$ A poem in that book, called "Freedom!" and dedicated to "the martyrs of justice," includes a few lines rather similar to the closing lines of the Shakespeare tribute:

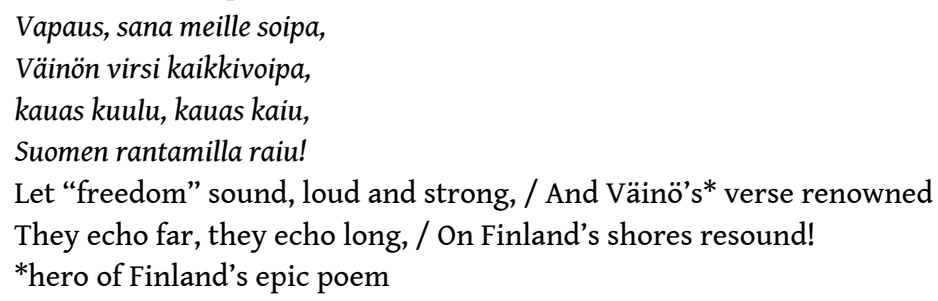

It is extremely hard to convey in English the energy of Leino's verse, the nationalistic aspirations embedded in the $/ \mathrm{k} /$ and other alliterations. The words kaiku [echo] and kerran [literally: once], which Leino uses in these and other poems, also allude to the closing of the Finnish national anthem, written some 70 years before independence and expressing the wishes of the Finnish people that one day their songs, too, would echo far. Therefore, I think that the weakening of the poem's political content can mainly be explained by the translator's lack of poetic skill, especially given the short time frame 
for both the writing and the translation of the poem. It is possible, however, that the translator, aware of political realities at home, sought to lighten the poem in order to avoid problems not with the English editor, but with the Finnish censor.

\section{The Poem Censored}

And indeed it is now to censorship that I turn, as we examine the after-life of the poem in Finland. Leino's poem was published twice more, under a different name. In A Book of Homage to Shakespeare, the poem is entitled "Shakespeare-Tunnelma," which roughly translates as "The Spirit" or "The Feeling of Shakespeare." On April 23, 1916, it appeared in the Shakespeare commemorative issue of Sunnuntai [Sunday], a weekly culture journal edited by Leino, under a title which literally translates as "Greetings to Shakespeare's Native Country." ${ }^{23}$ In small print just above the author's name at the bottom, it says "Poem published in a commemorative volume appearing around this time in England, written by EINO LEINO." ${ }^{24}$ As you can see (Figure 2), this version of the poem has been censored, as the last three lines are missing and there is a telltale white space between the last printed lines and the author's name. Editors tried to leave white space if a work had been censored in order to inform the public that something was missing, although legally they were not supposed to do this. You can also see the initials "S.H." at the bottom left, across from Leino's name, which stand for Sotasensuurin hyväksymä, or "approved by the military censor."

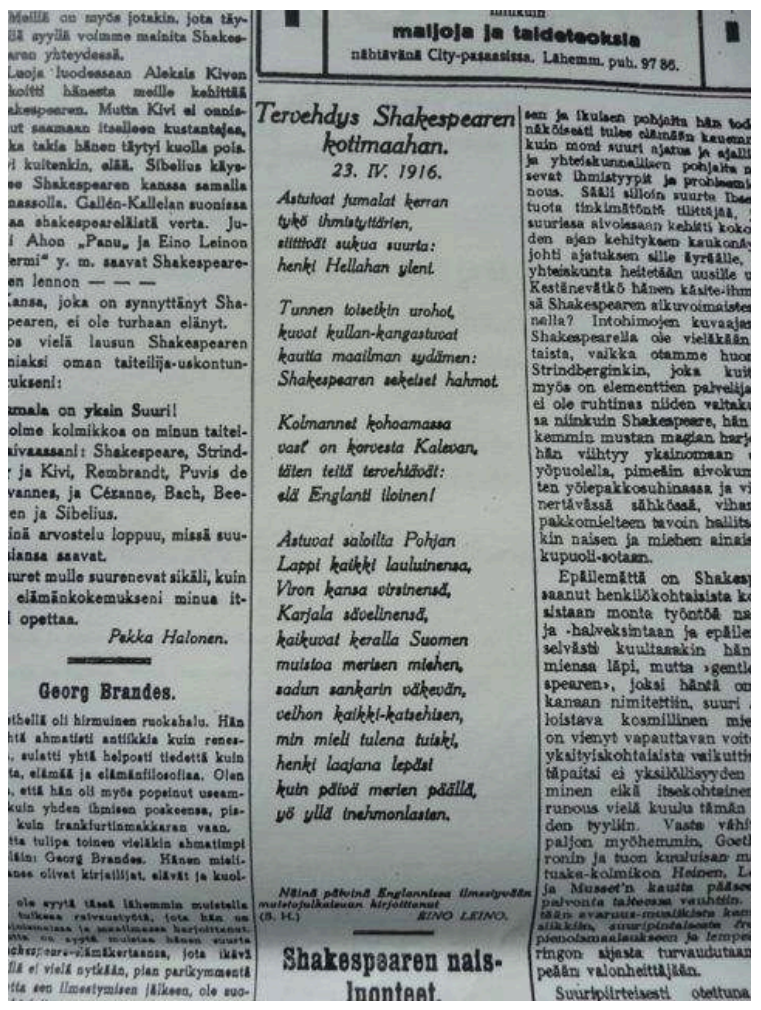

Figure 2: Censored poem in literary journal Sunnuntai, April 23, 1916

DOCUMENT AVAILABLE ON MICROFILM AT THE FINNISH NATIONAL LIBRARY. PHOTO BY N. KEINÄNEN, REPRODUCED WITH KIND PERMISSION OF THE LIBRARY. 
censored in wartime Finland. Censorship of the press had long been an instrument of Russian control, with Finnish being mentioned for the first time in 1850, in a law which forbade the publication of works in the Finnish language, except those connected to the Church or improving the economy. ${ }^{26}$ The Governor General at that time, Alexander Menshikov, commented that since nothing had been published in Finnish anyway, this prohibition was not taking anything away from the people. ${ }^{27}$ In 1854, permission was granted to publish "useful" works in Finnish, and in 1860 the prohibition on Finnish was officially repealed. Except for a brief period between 1865-67, preventive censorship was practiced, which meant that all works for publication needed to be pre-approved by a censor. A Printing High Council (Painoasiain ylihallitus) was established to oversee censorship in 1865. With the growth of a nationalist movement known as Fennomania, censorship became gradually more repressive. In 1885 the Governor General was granted the right to close down newspapers without warning. In 1891, laws were passed requiring that all books and newspapers be licensed, and that anyone who wanted to publish or sell print material also apply for a permit. The application for Leino's literary and cultural journal Sunnuntai [Sunday] can be found in the diaries of the Printing High Council, dated December 29, 1915 and approved on January 18, 1916. ${ }^{28}$

After the General Strike of 1905, some press freedoms were achieved, including the end of preventive censorship. In 1906 the Printing High Council itself was abolished, but a version of it was re-established in 1910. Everything changed again in 1914 with the advent of war in Europe. Wartime censorship brought back pre-publication screening and confiscation of offensive materials. Newspapers were considered particularly dangerous, and they were fined or closed down if they crossed the line too frequently or too egregiously. In 1916, restrictions were made on the importation of foreign materials, including English-language magazines. ${ }^{29}$

Leino himself was no stranger to censorship, and seems to have constantly tested its limits. As Larmola points out, at this time Finnish literature and journalism were still relatively young, and there were not a lot of domestic models on how to evade censorship. ${ }^{30}$ According to Leino-Kaukiainen, one strategy often employed was the use of nature imagery in metaphorical meanings, such as frost, snowstorms, thunderstorms, east and north winds, and raging rivers. ${ }^{31}$ For example, in 1899 Leino published a poem on the theme of fog, where prominent Helsinki landmarks, representative of the Russian government, were gradually covered in fog, leaving visible only the University of Helsinki, symbolizing the national Finnish-language culture. ${ }^{32}$ In 1903, one of the regional governors wrote to Governor General Bobrikov, complaining specifically about Leino. His works "which had passed through the censor" were "often recited on public occasions" in such a way that would give the listener "the wrong impression about the current situation and incite them (as for example the 
poem "The Artist's Night" and others)." ${ }^{33}$ So clearly the Russian authorities were aware of Leino's subversive tendencies, and moreover worried that people would use his poems as rallying cries for what they considered seditious activities. From Leino's point of view, it seems that a tribute to Shakespeare provided an ideal occasion for promoting freedom of the press in Finland, if not also for celebrating Finnish literature more broadly.

As far as I have been able to tell, nothing else was censored in the special Shakespeare commemorative issue of Sunnuntai (meaning that there is no other telltale white space). The offensive poem is placed on page six of an eight-page newspaper, not exactly buried but not given pride of place either. Can we see here a bit of anxiety, an unwillingness to give such a political poem a more prominent place? Interestingly, the first pages of the newspaper focus on the previous Shakespeare anniversary, the commemoration of 1864. For Finns, this had been significant as it had been marked by the first translation into Finnish of a complete Shakespeare play, Macbeth, translated by Kaarlo Slöör. At the top and center of page one is a long and politically safe article recalling this 1864 commemoration, written by Thiodolf Rein, a Finnish philosopher, politician and professor of some stature, who was 78 years old in 1916 and had been to that commemoration 52 years earlier. Curiously, Rein's article bears the S.H. mark of the censor, presumably due to Rein's radical past. A much less political poem, by Zachris Topelius, also read at the 1864 commemoration, is at the top of page two: it focuses on Shakespeare the man's exceptional personal qualities, and closes with the idea that in its commemoration of Shakespeare, Finland is being drawn closer to Europe. Interestingly from the modern point of view, for Finns in the early decades of the $20^{\text {th }}$ century, the English poet was linked to "Europe," not "England" or "Great Britain."

21 Aside from Leino's poem and the entirely safe contribution from a known radical which also bears the censor's mark, I do not think anything else in the 1916 Finnish commemorative newspaper would have raised the censor's eyebrow, with the possible exception of a rather negative comparison between Shakespeare, who represents "European" culture, and Tolstoy, representing "Asian." Europeans like Shakespeare, says the author, seek out the best in people, whereas "Asians" search for their sins or, conversely, turn them into saints. ${ }^{34}$ Shakespeare doesn't preach, whereas Tolstoy does. It was forbidden to make deprecating remarks about the Czar's family, the governments in Russia and in Finland, and so forth, but apparently it was allowed to criticize Russian literature.

\section{Censorship of Another Kind?}

This story of censorship in Finland has an odd footnote, though indeed it was this footnote which prompted me to study Leino's poem. There are at least two copies of the Homage in Finland, one in the National Library of Finland, and another in the University of Helsinki Library. The latter copy also bears the mark of a censor, though I cannot be sure whether this person was acting in an official capacity. The last three lines of the poem have been carefully cut out of both the Finnish original and the English translation, probably with a razor blade or other sharp object. Two clean holes, with the rest of the page intact. 
SHAKESPEARE-TUXCELMA

Astuvat jumalat kerram

tykö ihmistyttirien,

siittivait sukua suurta

Tunnen toisetkin urobiot,

kuvat kullan-kangastuvat

kautta maailman sydämen :

Shikopearen sekeiset hahmot.

Kolmannet kohoamassa

vast' on korvesta Kalevan,

clâ Englanti iloinen !

Astuvat saloilta Pohjan

Lappi kaikki lauluinensa,

Viron kansa virsinensia,

Karjala sâvelinensa,

kaikuvat keralla Suomen

muistoa merisen miehen,

sadum sankarin väkevïn,

vellion kaikki-katiochisen,

min micli tulena tuiski,

henki lajana leplisi

kuin paiva merien pảala,

yö yllĭ inchmonlasten.

Trunstation

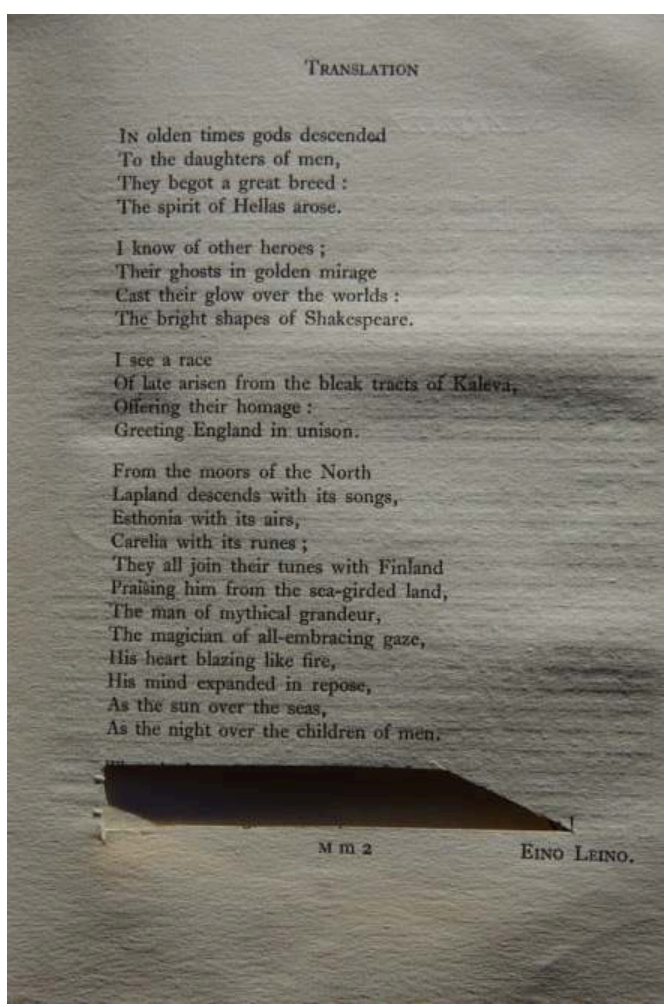

Figure 3: Censored Finnish and English facing pages of Eino Leino's "Shakespeare-Tunnelma" in University of Helsinki Library copy of Israel Gollancz, ed., A Book of Homage to Shakespeare

OXFORD, OXFORD UNIVERSITY PRESS, 1916, P. 534-535.

PHOTO BY N. KEINÄNEN, REPRODUCED WITH KIND PERMISSION OF THE LIBRARY. 
I am afraid that explaining these cuts belongs to the work of a novelist or playwright rather than literary critic. The official censor might have made these cuts the lines, but would have been more likely to remove the whole volume. Even more puzzling is the identity of the person who wrote out, on a piece of paper now brown with age, the words which had been cut out of the book, and tucked that paper into the book. A librarian, perhaps years later, distraught at finding the censored or vandalized book? A fan of Leino's, contemporary or later, who applauded his political agenda and wanted it to be known?

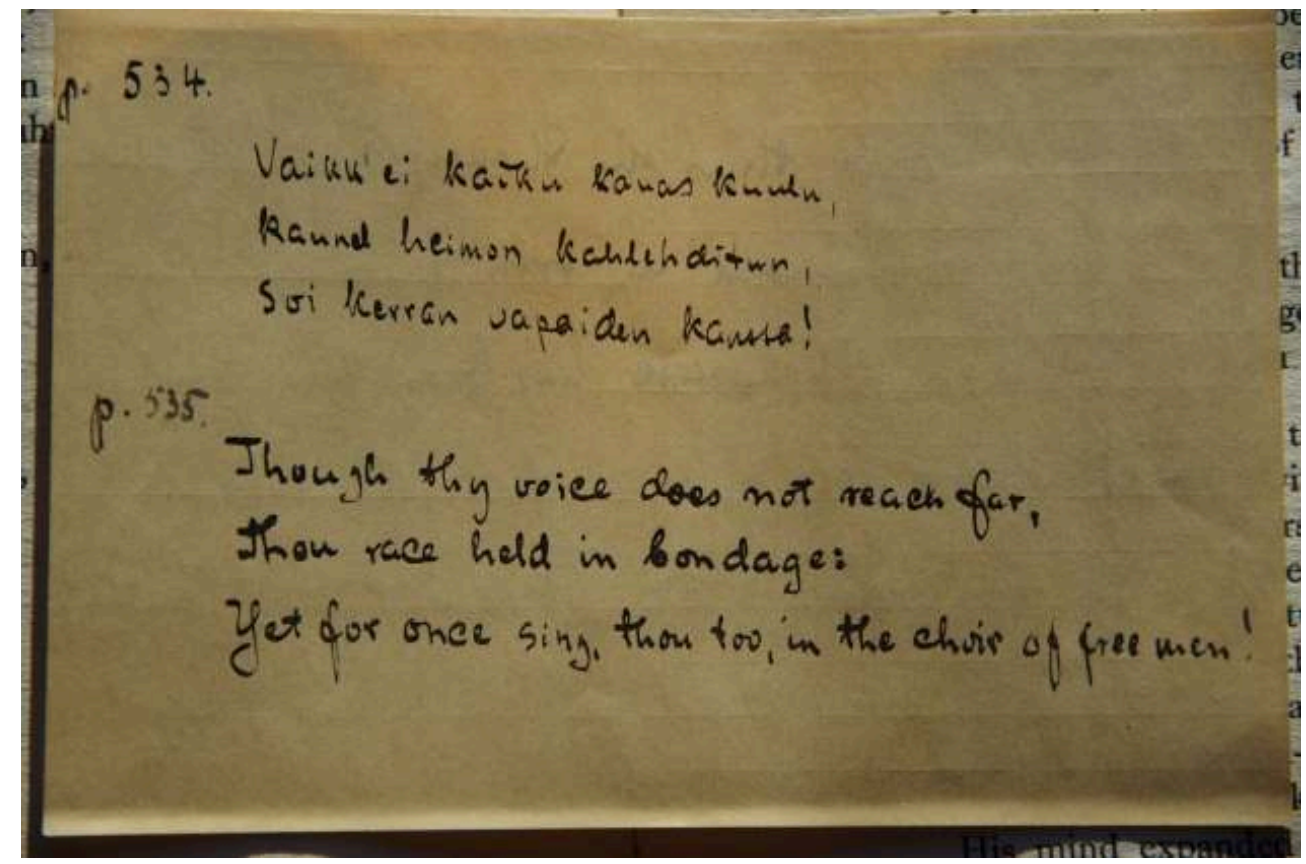

Figure 4: Paper tucked into University of Helsinki library copy of Israel Gollancz, ed., A Book of Homage to Shakespeare

OXFORD, OXFORD UNIVERSITY PRESS, 1916.

PHOTO BY N. KEINÄNEN, REPRODUCED WITH KIND PERMISSION OF THE LIBRARY.

These are questions I cannot answer. But what we do know is that in 1916, in Finland, Shakespeare commemoration became a rather complex site of nationalist expression, in which the leading poet of the Finnish language envisages Finnish literature as rising up to join the Greeks and Shakespeare, expresses his solidarity with other peoples oppressed by the Russians, and voices a wish-censored in his home country-that his people could sing "in the choir of free men." Alongside Douglas Hyde (Ireland), Solomon Tshekisho Plaatje (South Africa), and Maung Tin (Burma), Eino Leino provides another example of the way a minority language and culture sought to use "Shakespeare commemoration" for his own purposes. By examining the poem's afterlife in Finland, I have also shown the ways his effort to voice dissent and build national identity were thwarted. But as we can see in the effective use of a poetic form, the white space left floating above the censor's mark, or a piece of paper tucked into a book, Shakespeare commemoration also created space for small but significant acts of courage. Future scholars may well find similar examples in other Shakespeare commemorations. 


\section{NOTES}

1. Ton Hoenselaars and Clara Calvo, "Introduction: Shakespeare and the Cultures of Commemoration," Critical Survey 22.2, 2010, 1-10, p. 5.

2. Ibid., p. 7.

3. Claro Calvo, Shakespeare and Cervantes in 1916: The Politics of Language," in Shifting the Scene: Shakespeare in European Culture, Ladina Bezzola Lambert and Balz Engler, eds., Newark, University of Delaware Press, 2004, p. 78-94.

4. Clara Calvo, "Fighting over Shakespeare: Commemorating the 1916 Tercentenary in Wartime," Critical Survey 24.3, 2012, 48-72. Also see Ton Hoenselaars, "Great War Shakespeare: Somewhere in France, 1914-1919", in Dominique Goy-Blanquet and Laetitia Sansonetti, eds., Shakespeare 450, Actes des congrès de la Société française Shakespeare 33, 2015: http://shakespeare.revues.org/2960 (accessed September 8 2015).

5. Werner Habicht, "Shakespeare Celebrations in Times of War", Shakespeare Quarterly 52.4, Winter, 2001, 441-455; Richard Foulkes, Performing Shakespeare in the Age of Empire. Cambridge, Cambridge University Press, 2002. For a general study of Shakespeare commemoration, see Georgianna Ziegler, "Commemorating Shakespeare," in Shakespeare: An Oxford Guide, Stanley Wells and Lena Cowen Orlin, eds., Oxford, Oxford University Press, 2003, p. 658-672.

6. Israel Gollancz, A Book of Homage to Shakespeare, Oxford, Oxford University Press, 1916.

7. Coppélia Kahn, "Remembering Shakespeare Imperially: The 1916 Tercentenary," Shakespeare Quarterly, 52.4, Winter, 2001, 456-478.

8. Ibid., p. 478.

9. Habicht, op. cit., p. 450-51; Kahn, op. cit., p. 465-467.

10. Many thanks to Monika Smialkowska for checking the archive, and providing me with photos of the relevant materials.

11. Esko Piippo, personal communication, January 22, 2015. Piippo reports that in his travels, Leino never went to England, and could not speak English, though due to his otherwise excellent language skills he could understand English texts with the aid of dictionaries, translations into other languages, and interpreters. Around this time, Leino translated from English two works by Rabindranath Tagore into Finnish, one in 1913 and the other in 1917. Leino was aided at least in the second translation by L. Onerva, an outstanding Finnish poet in her own right. Further information is available in Finnish on the webpages of the Kainuu Eino Leino Society, www.kainuuneinoleinoseura.fi (accessed April 8 2015).

12. Yrjö Hirn, "Shakespeare in Finland," p. 536-537 and Juhani Aho, "Ensimäinen suomalainen Shakespearen ensi-ilta Suomessa" [The First Finnish-language Shakespeare Premiere in Finland], p. 538-542, both in Israel Gollancz, ed., op. cit.

13. Ibid, p. 538. Unless otherwise noted, all translations from the Finnish are my own.

14. Eino Lyytinen, Finland in British Politics in the First World War. Helsinki: Suomalainen Tiedeakatemia, 1980, esp. p. 31-73.

15. J. Dover Wilson, "Russia," in R. W. Seton-Watson, J. Dover Wilson, Alfred E. Zimmern and Arthur Greenwood, eds., The War and Democracy, London, 1915, p. 163. For further discussion of Dover Wilson's stance, see Terence Hawkes, "Telmah," in Patricia Parker and Geoffrey Hartman, eds., Shakespeare and the Question of Theory, London, Methuen, 1985, p. 310-332, esp. p. 318-331.

16. Lyytinen, op. cit., p. 68.

17. Ibid., p. 57-69. 
18. While many of the tributes in the Homage seem to rank Shakespeare as the pinnacle of English or world literary traditions, Leino's poem is by no means the only one in the Homage which attempts to situate Shakespeare in a broader literary context. For example, R. G. Moulten, Professor of Literary Theory and Interpretation at the University of Chicago, notes that the Renaissance period brought together "the three great things of literature: the newly recovered classics of ancient Greece, the mediaeval accumulations of romance, and a universally diffused Bible" (p. 229), though earlier he said that Shakespeare is "the mountain-top dominating the whole landscape" of world literature as seen "from the standpoints of the English-speaking civilization" (p. 228). H. J. C. Grierson, Professor English at the University of Edinburgh, traces a literary history from Chaucer to Sidney, Spenser and Drummond before getting to Shakespeare (p. 267-268).

19. Each table includes the Finnish original on the left, in the center column the English translation published on the facing page in the Homage (translator unknown), and in the third column my own translation, which attempts to capture the flavor of Leino's verse form and sound devices.

20. Thanks to Maria Salenius for discussing these issues with me.

21. Unfortunately I haven't been able to work the kantele or another musical instrument into the translation, so have stuck to the "song" of the preceding lines.

22. Painoasiain Ylihallituksen Painoasiamiesten kirjeitä 1915-1916. Aa41, item \#237, p. 116.

23. Leino was editor-in-chief of the journal, with L. Onerva serving as secretary. In her biography of Leino, Onerva explains that the journal's title, Sunday, "signified poetry in the deepest sense, which was Leino's religion. Poetry is sacred and the sacred is the same as poetry" (L. Onerva, Eino Leino: Runoilija ja Ihminen [Poet and Person], Helsinki, Otava, 1979, p. 453).

24. The poem appears on page 6 of the newspaper.

25. Eino Leino, “Tervehdys Shakespearen kotimaahan," Runot 2, Helsinki, Otava, 1985, p. 917-918.

26. Päiviö Tommila, "Sensuuriolot ennen vuotta 1865 [Censorship practices before 1865]," in Pirkko Leino-Kaukiainen, Sensuuri ja Sananvapaus Suomessa [Censorship and Freedom of Speech in Finland], in Suomen sanomalehdistön historia 17, 1980, 3-16, p. 12.

27. Yrjö Larmola, “Eino Leinon Tiet Sensuurin Ohitse” [Eino Leino's Strategies for Getting Past the Censor], in Vanhan Kirjallisuuden Vuosikirja 6, 1991, 84-93, p. 84. Finnish had first been written down by Mikael Agricola in the 1540 s, but was not written more widely until the mid-19 century, precisely when laws against it were being passed.

28. Painoasiain Ylihallituksen Diario 1915, Aa40, p. 255, item \#426.

29. Painoasiain Ylihallituksen Diario 1916, Aa43, item \#25.

30. Larmola, op. cit., p.88.

31. Ibid., p.85.

32. Ibid., p. 89.

33. Ibid., p. 92-93.

34. Sunnuntai, op. cit., p. 2-3.

\section{ABSTRACTS}

This article analyzes the contribution of the Finnish poet Eino Leino to A Book of Homage to Shakespeare, edited by Israel Gollancz and published by Oxford University Press in 1916. Leino's 
tribute to Shakespeare is also a call for freedom, effectively using the form of the Finnish national epic to emphasize its political message. The English translation is somewhat less political than the original. The poem was reprinted twice in Finland, and censored both times, though in starkly different ways. First it appeared in a literary journal edited by Leino, where the final three lines were cut due to their incendiary content. A copy of Homage now in the University of Helsinki library was also censored, with the offensive lines carefully cut out with a sharp instrument. At some point, somebody copied out the missing lines on a piece of paper now brown with age, and inserted them in the book. The analysis shows that like other oppressed peoples at the time, Finns sought to use "Shakespeare commemoration" for their own purposes, but also demonstrates their possible anxieties about doing so, and the ways their efforts to voice dissent and build national identity are thwarted. It also shows that Shakespeare commemoration created space for small but significant acts of courage.

Cet article analyse la contribution du poète finlandais Eino Leino au florilège $A$ Book of Homage to Shakespeare, publié sous la direction d'Israel Gollancz en 1916 (Oxford University Press). L'hommage de Leino à Shakespeare est un appel à la liberté qui utilise la forme de l'épopée nationale finlandaise pour faire passer un message politique, même si la traduction anglaise est moins politique que l'original. Le poème a connu deux rééditions en Finlande, et les deux fois il a été censuré, selon des modalités différentes. Il paraît d'abord dans un magazine littéraire dirigé par Leino ; les trois derniers vers sont alors expurgés à cause de leur contenu. Une édition de ce Book of Homage conservée à la bibliothèque de l'Université d'Helsinki a également été censurée : la portion de la page contenant les vers incriminés a été minutieusement découpée, mais les vers manquants ont fait leur réapparition, recopiés par une main inconnue sur un morceau de papier inséré dans l'ouvrage. L'analyse démontrera qu'à l'instar d'autres populations opprimées à l'époque, les Finlandais ont cherché à s'approprier les commémorations shakespeariennes, conscients des difficultés d'une telle entreprise. On montrera aussi, malgré l'échec de ces tentatives d'exprimer une pensée dissidente et de construire une identité nationale, que cette vague de commémorations a favorisé des actes de bravoure, limités mais lourds de sens.

\section{INDEX}

Keywords: 1916, Book of Homage to Shakespeare (A), censorship, commemoration, Gollancz Israel, Leino Eino, Shakespeare in Finland

Mots-clés: 1916, Book of Homage to Shakespeare (A), censure, commémoration, Gollancz Israel, Leino Eino, Shakespeare en Finlande

\section{AUTHOR}

\section{NELY KEINÄNEN}

University of Helsinki 